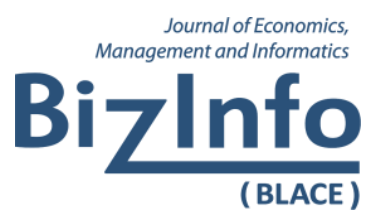

Year 2019, Volume 10, Number 2, pp. 25-41

Оригиналан научни рад/ Original scientific paper

УДК/UDC: 331.101.32-057.16

005.961:005.81]:640.412(497.11)

doi:10.5937/bizinfo1902025P

\title{
EMPLOYEE SATISFACTION IN HOTEL INDUSTRY: THE CASE OF HOTEL RADAN IN PROLOM BANJA
}

\section{ЗАДОВОЉСТВО ЗАПОСЛЕНИХ У ХОТЕЛИЈЕРСТВУ: ПРИМЕР ХОТЕЛ РАДАН У ПРОЛОМ БАЫИ}

\author{
Goran Perić ${ }^{1}$
}

Belgrade Business Academy for Applied Studies, Blace Department, Serbia

Sandra Dramićanin

University of Kragujevac, Faculty of Hotel Management and Tourism in

Vrnjačka Banja, Serbia

Branislav Sančanin

Union - Nikola Tesla University Belgrade, Faculty of Management, Sremski

Karlovci, Serbia

Abstract: Employees or human resources play a central role in the hotel industry. The quality of hotel employees' work depends primarily on their job satisfaction. This has directed the subject of the research in this paper to examine the key factors of employee satisfaction in the hotel industry. The survey was conducted using a questionnaire-based test method at the Radan Hotel in Prolom Banja, on a sample of 75 subjects. The most important finding of the research relates to the identification of key factors of employee satisfaction, the most important of which are the working environment of employees, interpersonal relations and communication of management with employees, as well as to the fact that there is not statistically significant influence between demographic variables of respondents and factors of employee satisfaction. Implications, research limitations and suggestions for future research are presented.

Key words: employee satisfaction, factors, service, hotel industry.

${ }^{1}$ goran.peric@vpskp.edu.rs 
Сажетак: Запослени, односно људски ресурси имају централну улогу у хотелијерству. Квалитет рада запослених у хотелијерству зависи у првом реду, од юиховог задовољства послом. То је усмерило предмет истражсивања у овом раду ка испитиваюу кључних фактора задовољства запослених у хотелијерству. Истраживање је спроведено употребом методе испитивања, техником упитника, у хотелу "Радан" у Пролом Бањи, на узорку од 75 испитаника. Најважнији налаз истражсивања односи се на идетификовање кључних фактора задовољства запослених, међу којима су најважнији, радно окружење запослених, међуљудски односи и комуникација менаимента са запосленима, као и да не постоји статистички значајан утицај између демографских варијабли испитаника и фактора задовољства запослених. Предочене су импликачије, ограничења истраживања и предлози за будућа истраживања.

Кьучне речи: задовољство запослених, фактори, услуга, хотелијерство.

\section{INTRODUCTION}

When employees of a service company are satisfied, they are motivated to dedicate themselves to completing their work tasks and achieving the company's goals. This is especially pronounced in the hotel and tourism industry, where consumer loyalty, making a purchasing decision, making repeated purchases and making recommendations depend on their perception and satisfaction, which are influenced directly or indirectly by employees (Perić et al., 2018).

At the hotel as the primary provider of tourism, tourists and employees are directed to cooperate with each other in the realization of the service, and how successful their interaction will be depends largely on the abilities, knowledge and skills of the employees in providing the services (Perić et al., 2015). As employee knowledge and skills are intangible assets of any service organization, employee satisfaction has become one of the most significant issues facing the hotel and tourism industry (Matzler and Renzl, 2007). The quality of work of hotel and tourism employees depends first and foremost on their job satisfaction. Satisfied employees tend to be more productive, positive and creative (Kong et al., 2018). However, what characterizes the hotel and tourism industry is the lack of qualified staff, that is, employees (Kim et al., 2014). In addition, hotel employees show low levels of job satisfaction, with high employee turnover (Kim et al., 2016; Lam et al., 2001). Dissatisfied employees exhibit deviant behavior at work and plan to leave it, which in turn diminishes service quality and affects business performance (Tuna et al., 2016; O'Neill and Davis, 2011). 
In the domestic professional and scientific literature, there are a small number of studies that have examined the various factors of hotel staff satisfaction. This has directed the subject of research in this paper to examine key factors of employee satisfaction. In order to achieve and maintain a competitive edge, hotel and tourism organizations use different strategies, which is why it is important to examine employee satisfaction in order to formulate an effective strategy and allocate more significant resources to increase employee satisfaction.

The aim of this research is to identify key factors of satisfaction of employees in the hotel industry. From the perspective of the concept of this research, the overall objective is operationalized through the following specific objectives:

- to analyze the impact of various organizational factors (managementemployee ratio, salaries and rewards, interpersonal relationships, education and training, work environment) on hotel employee satisfaction;

- to identify key factors of employee satisfaction;

- to check whether there are similarities and differences in employee satisfaction with respect to demographic variables (gender, education level, length of service).

\section{LITERATURE REVIEW}

Employee satisfaction, according to one of the first definitions of this term, is understood as a combination of psychological or environmental factors that make an employee happy with their job (Pavlovic \& Markovic, 2014). Locke (1976, p. 1297) defines employee satisfaction as a pleasant or positive emotional state resulting from the performance of a job or the overall experience of a job. According to Spector, satisfaction is what a person feels about the job and different aspects of the job (Borralha et al., 2016). Davis and Nestrom (1985) view employee satisfaction as a relatively simple concept which is a combination of positive and negative feelings that an employee feels about their work. According to these authors, employee satisfaction is closely related to the employee's behavior in the workplace and how much their expectations match the actual rewards they receive through work. Statt (2004), who also believes that employee satisfaction is manifested by how satisfied an employee is with the rewards they receive by doing their job, also join this understanding.

Lease (1998) points out that employees with higher levels of satisfaction have lower absenteeism rates, are more productive, more committed to the organization and its goals, and generally more satisfied with their lives. Similar thinking was expressed by Jessen (2010) that an employee who is satisfied at work is more productive and focused on achieving organizational 
goals. In addition, the results of the survey on employee satisfaction in Serbia indicate a positive correlation between employee satisfaction and organizational commitment of employees in the hotel industry (Blešić et al., 2017). Josanov-Vrgovic and Pavlovic (2018) point out that employee satisfaction influences organizational behavior and organizational performance. Sagger, Rafat, and Agarwal (2012) indicate that a number of organizational factors influence the level of employee satisfaction. Employees spend a lot of time at work, and it is therefore logical that most factors from the organization's environment have an impact on employee satisfaction. Employee satisfaction can be improved through the management of organizational factors such as: organizational development, reward system, career progression and development, work environment, management relations, teamwork and more (Djokic et al., 2015; Peric et al., 2015 ; Robbins and Judge, 2009). In addition to organizational factors, employee satisfaction is also influenced by demographic characteristics of employees such as gender, length of service, level of education, as well as personal factors such as position and status, life satisfaction, etc. The assumption of the influence of demographic characteristics on employee satisfaction is supported by the results of numerous empirical studies (Clark, 1997; Verhofstadt et al., 2007; Franěk and Vecer, 2008; Kara et al., 2012; Urosevic and Milijic, 2012). It should also be noted that the results are quite inconsistent, that is, certain surveys did not confirm the effect of demographic characteristics on employee satisfaction (El Khouly et al., 2011; Ghafoor, 2012; Rast and Tourani, 2012), and that some studies found that women had have higher levels of job satisfaction compared to their male counterparts, and vice versa (Sousa-Poza and Sousa-Poza, 2003; Long, 2005; Mihajlov et al., 2015).

Surveys conducted among employees in hotels in Hungary indicate that the main predictors of employee satisfaction are recognition, involvement in decision-making, career levels, salaries and benefits (Ineson, Benke and Laszlo, 2013). The results obtained by Tepaci and Bartlett (2012) show that satisfaction is based on individual values and organizational factors such as organizational culture.

Managers, whose job is to know how their employees feel at work and what their preferences are, play an important role in hotel employee satisfaction. The level of commitment of employees in achieving the goals of the hotel depends on their expectations that the effort put in will lead to the satisfaction of their wishes and needs. In this context, the key to employee satisfaction lies in managers' understanding about what employees want from their job (Lam, Zhang and Baum 2001).

Numerous empirical studies conducted in the hotel industry (Koys, 2003; Yee, Yeung and Cheng, 2008; Jung, and Yoon, 2013) indicate significant 
effects of employee satisfaction on creating and maintaining customer satisfaction and loyalty, resulting in higher sales, profitability and the competitiveness of the service organization. Thus, having a loyal customer base in a turbulent competitive environment increases profits, lowers costs, and increases market share (Nadiri and Tanova, 2010).

\section{METHODOLOGY}

The collection of primary data was conducted using a questionnaire-based method of inquiry, which includes a survey method that systematically collects data from a set of respondents in the form of personal views. The research started with the following hypotheses:

H1: Good employee relations are the most important factor in employee satisfaction.

$\mathrm{H} 2$ : There is no statistically significant influence between the respondents' length of service and the factor of satisfaction of the employees with the highest and lowest scores.

H3: There is no statistically significant influence between the gender of the respondents and the factors of satisfaction of the employees with the highest and lowest scores.

A questionnaire was developed for research purposes. The first part of the questionnaire contains questions about the demographic characteristics of the respondents, and the second part of the questionnaire contains statements related to various factors of employee satisfaction, followed by variants of respondents' statements according to the five-level Likert scale. For each of these statements the respondent expressed a degree of agreement, which is entered as a score of 1 to 5 (meaning: $1=$ Disagree at all; $2=$ Disagree; $3=$ Not sure; 4 = Agree and $5=$ I totally agree). Employee satisfaction factors (management-employee relationship, pay and reward, interpersonal relationships, education and training, work environment) were selected based on a literature review (Lawler and Porter, 1967; Christen, Iyer and Soberman., 2006; Singh and Jain, 2013).

The survey was conducted at the end of December 2018 in Prolom Banja, at the Radan Hotel, on a sample of 75 respondents. In the initial phase of the research it was explained to the respondents that the research was anonymous and that the data obtained would be used solely for research purposes. Furthermore, in order to obtain oral informed consent and respect for the principles of voluntariness and anonymity, the respondents were explained the procedure, purpose and objectives of the research, as well as the wayof using the obtained statements. Data processing was carried out by a quantitative analysis of the content of the collected empirical survey questionnaires. Statistical analyzes were conducted within the statistical 
package SPSS 20.0 (Statistical Package for Social Sciences for Windows 20.0). The following statistical techniques and methods were applied in the statistical data processing and testing of the hypotheses:

- Descriptive statistical measures - frequencies and percentages were used to describe the research sample.

- Measurements of variability - arithmetic mean (M) and standard deviation (SD) - were used to show the expression of scores on the questionnaires.

- ANOVA and significance (F) analysis of variance was used to show significance and differences between scores on individual variables.

- Pearson's linear correlation coefficient was used to test the association between the variables.

\section{ANALYSIS AND DISCUSSION OF RESULTS}

Statistical data processing includes a sample of 75 respondents consisting of employees of the Radan Hotel in Prolom Banja, operating within the AD "Planinka" from Kursumlija.

Table 1. Sample structure representation

\begin{tabular}{|c|c|c|c|}
\hline $\begin{array}{c}\text { Demographic } \\
\text { variables }\end{array}$ & Variable categories & Frequency & Percentage \\
\hline \multirow{2}{*}{ Gender } & Male & 30 & 40 \\
\cline { 2 - 4 } & Female & 45 & 60 \\
\hline \multirow{4}{*}{ Years of service } & Up to 5 years & 16 & 21.3 \\
\cline { 2 - 4 } & $6-10$ & 17 & 22.7 \\
\cline { 2 - 4 } & $10-20$ & 21 & 28 \\
\cline { 2 - 4 } & Over 20 years & 20 & 26.7 \\
\hline \multirow{3}{*}{$\begin{array}{c}\text { Degree of } \\
\text { education }\end{array}$} & High school & 41 & 22.7 \\
\cline { 2 - 4 } & College & 17 & 14.7 \\
\cline { 2 - 4 } & Bachelor degree & 11 & 4 \\
\cline { 2 - 4 }
\end{tabular}

Source: Author's Calculation

Given the gender structure and the specificity of the sample of respondents, such gender participation was expected. The above previous table shows that women are the most employed in the Radan Hotel, and in our sample their participation is $60 \%$. Male respondents represented $40 \%$ of the sample. The seniority variable is classified into four categories, and each of them is represented in our sample. The number of respondents with 10-20 years of service and over 20 years of service (28\% and 26.7), as well as up to 5 years of service and 6-10 years (21.3\% and 22.7\%), is almost equal. One respondent did not answer this question (1.3\%). In terms of educational attainment, the respondents mostly have secondary school degree (54.6\%), followed by the respondents with collage $(22.7 \%)$ and bachelor's degree 
$(14.7 \%)$. The smallest numbers of respondents have a master's degree or $\mathrm{PhD}$ degree (4\%).

As the number of respondents is $\mathrm{N}=75$, general conclusions and trends can be drawn from this sample, based on which the research hypotheses will be answered. It can be said that all categories of variables, except the category of employees with a master/doctorate degree, with only three respondents, satisfy the basic criterion for statistical processing, which is the frequency of 5 respondents per category for a given variable.

The data are presented in tables of descriptive statistics, with arithmetic means as measures of the level of satisfaction of the employees at the Radan Hotel, with the aim of identifying the most important factors that influence the level of employee satisfaction and the answer to the first hypothesis, and in order to analyze specific research objectives. The average value on a fivepoint scale reflects the extent to which a given factor is rated as positive, and differences in scores, i.e. values of arithmetic means on individual statements, will be discussed in the analysis of the results. Also, in order to test the second and third hypotheses, analysis of variance by demographic variables of gender and length of service, representing the most important characteristics of the population, was applied in relation to which statistically significant differences will be discussed, as well as the correlation between the variables with respect to the highest score employee satisfaction factors. The analysis of research results will start with specific research objectives. First, the various factors of employee satisfaction at the Radan Hotel will be analyzed, as illustrated in Table 5.

Table 2. Key factors of employee satisfaction

\begin{tabular}{|c|c|c|c|c|c|}
\hline $\begin{array}{c}\text { Claims about employee } \\
\text { satisfaction factors }\end{array}$ & $\mathbf{N}$ & Min. & Max. & Mean & $\begin{array}{c}\text { Standard } \\
\text { Deviation }\end{array}$ \\
\hline $\begin{array}{c}\text { Management has good } \\
\text { communication with } \\
\text { employees }\end{array}$ & 75 & 2 & 5 & 4.21333333 & 0.858869989 \\
\hline $\begin{array}{c}\text { Management involves } \\
\text { employees in decision } \\
\text { making }\end{array}$ & 75 & 1 & 5 & $\mathbf{3 . 9 7 3 3 3 3}$ & 0.869503 \\
\hline Job training provided & 74 & 1 & 5 & 4.22972973 & 1.0006477 \\
\hline Salary satisfaction & 75 & 2 & 5 & 4.093333333 & 0.87260612 \\
\hline $\begin{array}{c}\text { Satisfaction with the work } \\
\text { environment }\end{array}$ & 75 & 2 & 5 & 4.28 & 0.688908263 \\
\hline $\begin{array}{c}\text { The reward system is } \\
\text { efficient }\end{array}$ & 73 & 2 & 5 & 4.054794521 & 0.895830015 \\
\hline Good employee relations & 75 & 2 & 5 & 4.2 & 0.80538727 \\
\hline General job satisfaction & 75 & 2 & 5 & $\mathbf{4 . 4 2 6 6 6 6 6 7}$ & 0.71985985 \\
\hline
\end{tabular}

Source: Author's Calculation 
It can be stated that overall job satisfaction has the highest score $(M=4.43)$. The factors underlying the high level of employee satisfaction, which are quite uniform in terms of scores, are: satisfaction with the work environment $(\mathrm{M}=4.28)$, training and job training provided $(\mathrm{M}=4.23)$, good management communication with employees $(\mathrm{M}=4.21)$ and good employee relations $(\mathrm{M}=4.2)$. Interestingly, overall job satisfaction is greater than each individual factor, indicating that either there is another important factor affecting job satisfaction, or it is the case that when a very favorable overall impression is decomposed into individual elements, one gets better insight and a more realistic assessment of the various aspects of the job. The smallest score has a factor - management involves employees in decision making $(\mathrm{M}=3.97)$. In line with the results obtained, the first hypothesis is rejected, although good employee relations have a high score $(\mathrm{M}=4.2)$ but not the highest.

The following tables of analysis of variance show statistically significant differences and associations with respect to demographic variables of gender and years of service. Three factors of employee satisfaction were selected, namely the factor with the lowest score (management includes employees in decision making $M=3.97$ ), the factor with the highest score (general job satisfaction $\mathrm{M}=4.43$ ), as well as the factor with salary satisfaction.

Table 3. Representation of statistically significant differences and influence of individual factors of employee satisfaction in relation to demographic

variable - gender

\begin{tabular}{|c|c|c|c|c|c|}
\hline Factors & $\begin{array}{c}\begin{array}{c}\text { Years of } \\
\text { service }\end{array} \\
\end{array}$ & Mean & $\begin{array}{l}\text { Standard } \\
\text { Deviation }\end{array}$ & $\mathbf{F}$ & Signaficant \\
\hline \multirow{2}{*}{$\begin{array}{c}\text { Management } \\
\text { involves } \\
\text { employees in } \\
\text { decision making }\end{array}$} & $\mathrm{M}$ & 4.1875 & 0.6445 & \multirow[b]{2}{*}{3.50114} & \multirow[b]{2}{*}{.065227} \\
\hline & $\mathrm{F}$ & 3.8222 & 0.9603 & & \\
\hline \multicolumn{6}{|c|}{$\mathrm{F}=3.50114 ; \mathrm{P}=0.065227 ; \mathrm{P}<0.05$} \\
\hline \multirow{2}{*}{$\begin{array}{l}\text { General job } \\
\text { satisfaction }\end{array}$} & $\mathrm{M}$ & 4.5 & 0.6222 & \multirow{2}{*}{0.36149} & \multirow{2}{*}{.549491} \\
\hline & $\mathrm{F}$ & 4.4 & 0.7804 & & \\
\hline \multicolumn{6}{|c|}{$\mathrm{F}=0.36149 ; \mathrm{P}=0.549491 ; \mathrm{P}<0.05$} \\
\hline \multirow{2}{*}{$\begin{array}{c}\text { Salary } \\
\text { satisfaction }\end{array}$} & $\mathrm{M}$ & 4.2188 & 0.8322 & \multirow{2}{*}{0.74267} & \multirow{2}{*}{.391554} \\
\hline & $\mathrm{F}$ & 4.0444 & 0.9034 & & \\
\hline
\end{tabular}

Source: Author's Calculation

When it comes to statistically significant differences in this demographic variable, it can be concluded that there is a difference between men and women in relation to management, as the results of the research suggest that management is more involved with men in decision making. There is no statistically significant effect of the demographic variable gender on the observed employee satisfaction factor - management involves employees in decision making $(\mathrm{F}=3.50114 ; \mathrm{P}=0.065227 ; \mathrm{P}<0.05)$. 
The difference in overall job satisfaction between male and female workers is almost non-existent, since the scores between the two variables are almost identical $(\mathrm{M}=4.5)$ and $(\mathrm{M}=4.4)$ as for general job satisfaction, there is no statistically significant relationship with the observed demographic variable $(\mathrm{F}=0.36149 ; \mathrm{P}=0.549491 ; \mathrm{P}<0.05)$.

With respect to the observed factor, salary satisfaction, the results indicate that there are differences between men and women, that is, men are more satisfied with salary $(M=4.22)$ than women $(M=4.04)$. The results obtained by analysis of variance indicate that there is no statistically significant influence between the gender structure of employees and satisfaction with the wage $(\mathrm{F}=0.74267 ; \mathrm{P}=0.391554 ; \mathrm{P}<0.05)$.

Based on the analysis of the results, the second hypothesis is confirmed because no statistically significant influence was found between the gender of the respondents and the variable highest job satisfaction with the highest score and the variable management included employees in decision making with the lowest score.

Table 4. Representation of statistically significant differences and impact of individual factors of employee satisfaction in relation to demographic variable - seniority

\begin{tabular}{|c|c|c|c|c|c|}
\hline Factors & $\begin{array}{c}\text { Years of } \\
\text { service }\end{array}$ & Mean & $\begin{array}{l}\text { Standard } \\
\text { Deviation }\end{array}$ & $\mathbf{F}$ & Significant \\
\hline \multirow{4}{*}{$\begin{array}{l}\text { Management } \\
\text { involves } \\
\text { employees in } \\
\text { decision } \\
\text { making }\end{array}$} & Up to 5 years & 3.8125 & 1.0468 & \multirow{4}{*}{0.59562} & \multirow{4}{*}{619877} \\
\hline & $6-10$ & 4.1176 & 0.8575 & & \\
\hline & $10-20$ & 3.8636 & 0.8888 & & \\
\hline & $\begin{array}{c}\text { Over } 20 \\
\text { years }\end{array}$ & 4.0909 & 0.6838 & & \\
\hline \multicolumn{6}{|c|}{$\mathrm{F}=0.59562 ; \mathrm{P}=0.619877 ; \mathrm{P}<0.05$} \\
\hline \multirow{4}{*}{$\begin{array}{l}\text { General job } \\
\text { satisfaction }\end{array}$} & Up to 5 years & 4.3125 & 0.8732 & \multirow{4}{*}{1.21148} & \multirow{4}{*}{.311682} \\
\hline & $6-10$ & 4.6471 & 0.6063 & & \\
\hline & $10-20$ & 4.5455 & 0.5958 & & \\
\hline & $\begin{array}{c}\text { Over } 20 \\
\text { years }\end{array}$ & 4.2727 & 0.7673 & & \\
\hline \multicolumn{6}{|c|}{$\mathrm{F}=1.21148 ; \mathrm{P}=0.311682 ; \mathrm{P}<0.05$} \\
\hline \multirow{4}{*}{$\begin{array}{c}\text { Salary } \\
\text { satisfaction }\end{array}$} & до 5 & 3.4375 & 1.0935 & \multirow{4}{*}{4.71524} & \multirow{4}{*}{.004601} \\
\hline & $6-10$ & 4.2353 & 0.5623 & & \\
\hline & $10-20$ & 4.3182 & 0.7799 & & \\
\hline & преко 20 & 4.3182 & 0.7799 & & \\
\hline \multicolumn{6}{|c|}{$\mathrm{F}=4.71524 ; \mathrm{P}=0.04601 ; \mathrm{P}<0.05$} \\
\hline
\end{tabular}

Statistically significant differences in the demographic variable length of service are present to a large extent in the younger population of employees (up to 5 years) and in the population of employees with length of service between 10 and 20 years, who are dissatisfied with the management and 
employee involvement in decision making. There are almost no differences in the rest of the research population, as the results of the research indicate that management involves more in deciding the population of employees with longer working lives between 6-10 and over 20 years. The results indicate that there is no statistical correlation between factors - management includes decision-makers and demographic variables of length of service $(\mathrm{F}=0.59562$; $\mathrm{P}=0.619877 ; \mathrm{P}<0.05)$.

As for general job satisfaction, there are no statistically significant differences with respect to the demographic variable length of service. As indicated, these results show that either there is another important factor affecting job satisfaction, or is that when a very favorable overall impression is decomposed into individual elements, a better insight and a more realistic assessment of different aspects of the job are accomplished. There was no statistically significant relation for the observed variables $(\mathrm{F}=1.21148$; $\mathrm{P}=0.311682 ; \mathrm{P}<0.05)$.

In relation to salary satisfaction, the results of the survey indicate that the younger population of employees with length of service up to 5 years is significantly more dissatisfied with the salary $(M=3.44)$ than other categories of employees, and especially than those with the longest working experience $(\mathrm{M}=4.32)$. The results of the research indicate that there is a statistically significant influence of the length of the respondents' work experience on the observed indicator of salary satisfaction $(\mathrm{F}=4.71524 ; \mathrm{P}=0.0460 ; \mathrm{P}<0.05)$.

Between the length of the respondents' work experience and the variables, general job satisfaction and management include employees in decisionmaking, which have the largest or the lowest score; there is no statistically significant influence, so that the third hypothesis is confirmed.

In further analysis of key factors of employee satisfaction, the table of correlations between general job satisfaction and individual factors of employee satisfaction follows.

Table 5. Correlation of employee satisfaction factors with general job satisfaction

\begin{tabular}{|c|c|}
\hline \multirow{2}{*}{ Employee satisfaction factors } & General job satisfaction \\
\cline { 2 - 2 } & Pearson correlation (r) \\
\hline Management has good communication with employees & 0,572074 \\
\hline Management involves employees in decision making & 0,536579 \\
\hline Job training provided & 0,599233 \\
\hline Salary satisfaction & 0,581139 \\
\hline Satisfaction with the work environment & $\mathbf{0 , 8 4 5 8 2 5}$ \\
\hline The reward system is efficient & $\mathbf{0 , 6 2 4 3 7 9}$ \\
\hline Good employee relations & $\mathbf{0 , 7 1 3 2 4 2}$ \\
\hline General job satisfaction & 1 \\
\hline
\end{tabular}

Source: Author's Calculation 
A coefficient score above 0.6 indicates a high degree of correlation between the variables, a score between 0.4 and 0.6 indicates a moderate correlation, and below 0.4 indicates a weak correlation. Obviously, all individual factors of employee satisfaction correlate with general job satisfaction, but what stands out as the most important are the reward system, good interpersonal relationships, and job satisfaction as the factors most correlating with overall job satisfaction. Thus, the work environment, a reward system and good interpersonal relationships leave the best impression on employees.

The aim of the research in this paper was to identify key factors of satisfaction of hotel employees. The first important finding relates to the fact that overall job satisfaction on the sample examined has a very high score $(\mathrm{M}=4.43)$. Furthermore, it can be stated that the employees are satisfied with all aspects of the job because scores on all factors have a value over 4, except for the factors - management involves employees in deciding, whose score is $(M=3.97)$. The factors most employed are the most satisfied: satisfaction with the work environment $(\mathrm{M}=4.28)$, training and job training provided $(\mathrm{M}=4.23)$, good management communication with employees $(\mathrm{M}=4.21)$ and good employee relations $(M=4.2)$. In one of the previous studies involving employees of the Radan Hotel, employee relations and training were poorly assessed, respectively, by scores $(\mathrm{M}=3.37)$ and $(\mathrm{M}=3.96)$, while the level of satisfaction with the work environment was assessed (M=3.88) (Peric, 2014). Higher employee satisfaction at the Radan Hotel is a result of the efforts of the management of the Hotel and the Planinka Company to improve the factors that influence employee satisfaction.

Analysis of variance indicates that there are statistically significant differences when it comes to employee demographic variables. The analysis shows that women are significantly less involved in decision-making by management. This is an important consideration given that women make up an important share of employees in the hotel and tourism industry. Although this issue is not the focus of the research, it is important to point out the necessity of gender equality for women and men employed in the hotel industry and to draw attention to the need for further and deeper exploration of the hierarchical structure of hotel employees in relation to gender and women's participation in decision making. The results obtained are in line with previous research conducted in the hotel industry in Croatia (Maskarin, 2005), which found a statistically significant difference when it comes to men and women in all observed employee satisfaction variables. Research conducted in the hotel industry of China indicates that employee satisfaction varies with gender and age (Tian and $\mathrm{Pu}, 2008$ ). 
Another statistically significant difference in employee satisfaction was found on the length of service variable. Namely, the population of employees with the least work experience is the least satisfied with the salary, compared to other categories. This population is also unhappy with management's attitude regarding employee involvement in decision making. The obtained research results indicate that there is a statistically significant influence of the length of the respondents' work experience in relation to the variable salary satisfaction.

Researchers are not unanimous in whether demographic variables such as gender, length of service, educational level, and other variables affect employee satisfaction. Some studies show that demographic variables have a negligible impact (Zhen and Jie, 2009; El Khouly et al., 2011; Ghafoor, 2012), while other studies indicate that demographic variables have a statistically significant impact or are strong predictors of employee satisfaction (Lam, Zhang and Baum 2001; Tian and Pu, 2008). It is important for hotel managers to identify demographic attributes that are attributed to affecting employee satisfaction or not, as they can develop appropriate strategies for increasing employee satisfaction for those groups of employees who have lower levels of job satisfaction (Mashkarin, 2005).

Correlations between general job satisfaction and individual factors of employee satisfaction have identified important correlations that point to the relationship between general job satisfaction and employee satisfaction factors. This finding confirms that all individual factors of employee satisfaction correlate with general job satisfaction, whereas and job satisfaction, good employee relationships and a reward system leave a better impression on employees. So what motivate employees to be up to the task are these three factors in the first place. This finding should not be taken literally, as other factors of employee satisfaction should not be overlooked, however, as a key recommendation to the hotel management may be the need for effective policies regarding the system of remuneration, improvement of the working environment and salaries of employees in order to increase their motivation and job satisfaction.

\section{CONCLUSION}

This paper identifies key factors for hotel staff satisfaction. According to the results, the answers to the hypotheses were given and it was found that general job satisfaction had the highest score and that there was no statistically significant influence between the demographic variables of the respondents and the factors of satisfaction of the employees with the highest and lowest scores. However, it is important for hotel management to recognize the demographic attributes that are attributed to affecting or not affecting employee satisfaction, as they can develop appropriate strategies for 
increasing employee satisfaction for those groups of employees who have lower levels of job satisfaction.

Based on the results of this research, it can be concluded that in the Radan Hotel the main predictors of employee satisfaction are working conditions and working environment of employees, relations with management, interpersonal relations, salaries and remuneration system. Also, when it comes to the category of youngest employees and part-time employees, the most important factor in satisfying this category of employees is pay, which is an important piece of information in terms of motivating young employees. A special recommendation to hotel management, but also to the hotel industry in general, is the need to promote gender equality more intensively and to equalize the participation of employees of both sexes in decision making and cooperation with management.

It is necessary to point out some limitations of this research and to take into account the fact that a modest sample of respondents (75) does not provide the basis for certain more general conclusions and allows only a partial insight into the satisfaction of hotel employees. In addition to a modest sample and research oeuvre, the limitation also refers to the application of a questionnaire that was created for research purposes, and is not standardized and sufficiently reliable. Therefore, one of the recommendations for further research may be the need for broader research using standardized questionnaires. This would allow the construction of a theoretical framework that would advance the understanding of the importance of employee satisfaction, which is still at an insufficient level in our country.

Without quality service, there are no loyal guests and good business results, and the focus of the quality of services in the hotel industry depends on the employees. It is therefore of primary importance for hotel managers to take care of employees and to work on improving those factors that cause their dissatisfaction.

\section{REFERENCES}

1. Blešić, I., Pivac, T. i Divjak, T., 2017. Efekti zadovoljstva poslom na orgnizacionu privrženost zaposlenih $\mathrm{u}$ hotelijerstvu. Poslovna ekonomija 11(2), str.114-132.

2. Borralha, S., Jesus, S. N., Pinto, P. and Viseu, J., 2016. Hotel employees: A systematic literature review. Tourism \& Management Studies, 12(1), pp.120-126.

3. Clark, A. E., 1997. Job satisfaction and gender: why are women so happy at work?. Labour economics, 4(4), pp.341-372. 
4. Christen, M., Iyer, G. and Soberman, D., 2006. Job Satisfaction, Job Performance, and Effort: A Reexamination Using Agency Theory. Journal of Marketing, 70, pp.137-150.

5. Davis, K., \& Nestrom, J.W., 1985. Human Behavior at work: Organizational Behavior, 7 edition, New York: McGraw Hill.

6. Đokić, T., Pepur, M. i Arnerić, J., 2015. Utjecaj zadovoljstva zaposlenika na zadovoljstvo korisnika na tržištu financijskih usluga. Ekonomska misao i praksa, (1), str. 49-79.

7. El Khouly, S., Ghoniem, A., Ghadami, M. and Ibrahim, M., 2011. Impact of emotional intelligence and gender on job satisfaction among Egyptian government sector employees. Current Research Journal of Social Sciences, 3(1), pp.22-27.

8. Franěk, M. and Večeřa, J., 2008. Personal characteristics and job satisfaction. E+M Ekonomie a Management/E+ $M$ Economics \& Management, 2008(4), pp.63-76

9. Ghafoor, M. M., 2012. Role of demographic characteristics on job satisfaction. Far East Research Centre, 6(1), pp.30-45.

10. Ineson, E. M., Benke, E. and Laszlo, J., 2013. Employee loyalty in Hungarian hotels. International Journal of Hospitality Management, 32, pp.31-39.

11. Jessen, J.T., 2010. Job satisfaction and social rewards in the social services. Journal of Comparative Social Work, 5(1), pp.1-18.

12. Josanov-Vrgovic, I. and Pavlovic, N., 2014. Relationship between the school principal leadership style and teachers job satisfaction in Serbia. Montenegrin Journal of Economics, 10(1), pp.43-57.

13. Jung, H. S. and Yoon, H. H., 2013. Do employees' satisfied customers respond with an satisfactory relationship? The effects of employees' satisfaction on customers' satisfaction and loyalty in a family restaurant. International Journal of Hospitality Management, 34, pp. $1-8$

14. Kara, D., Uysal, M. and Magnini, V. P., 2012. Gender differences on job satisfaction of the five-star hotel employees: the case of the Turkish hotel industry. International Journal of Contemporary Hospitality Management, 24(7), pp.1047-1065.

15. Kim, G., Ro, H., Hutchinson, J. and Kwun, D. J., 2014. The effect of jay-customer behaviors on employee job stress and job satisfaction. International Journal of Hospitality \& Tourism Administration, 15(4), pp.394-416.

16. Kim, M., Knutson, B. J. and Choi, L., 2016. The effects of employee voice and delight on job satisfaction and behaviors: Comparison between employee generations. Journal of Hospitality Marketing \& Management, 25(5), pp.563-588. 
17. Kong, H., Jiang, X., Chan, W. and Zhou, X., 2018. Job satisfaction research in the field of hospitality and tourism. International Journal of Contemporary Hospitality Management, 30(5), pp.2178-2194.

18. Koys, D. J., 2003. How the achievement of human-resources goals drives restaurant performance. The Cornell Hotel and Restaurant Administration Quarterly, 44(1), pp.17-24.

19. Lam, T., Zhang, H. and Baum, T., 2001. An investigation of employees' job satisfaction: the case of hotels in Hong Kong. Tourism management, 22(2), pp.157-165.

20. Lawler, E. E. and Porter, L. W., 1967. The effect of performance on job satisfaction. Industrial relations: A journal of Economy and Society, 7(1), pp.20-28.

21. Lease, S. H., 1998. Annual review, 1993-1997: Work attitudes and outcomes. Journal of Vocational Behavior, 53(2), pp.154-183.

22. Locke, E., 1976. The nature and causes of job satisfaction. In M. D. Dunnette (Ed.). Handbook of industrial and organizational psychology, 1297-1349). Chicago: Rand McNally.

23. Long, A., 2005. Happily ever after? A study of job satisfaction in Australia. Economic Record, 81(255), pp.303-321.

24. Matzler, K. and Renzl, B., 2007. Assessing asymmetric effects in the formation of employee satisfaction. Tourism Management, 28(4), pp.1093-1103.

25. Maškarin, H., 2005. Zadovoljstvo poslom zaposlenika u hotelskoj industriji Hrvatske. Tourism and hospitality management, 11(1), str. 193-206.

26. Mihajlov, S., Perić, G. i Mihajlov, N., 2015. Rodne razlike u zadovoljstvu poslom državnih službenika. $U$ : Zbornik radova Međunarodna naučna konferencija iz oblasti informacionih tehnologija i savremenog poslovanja: SYNTHESIS. Beograd, Srbija (675-679). Beograd: Univerzitet Singidunum.

27. Nadiri, H. and Tanova, C., 2010. An investigation of the role of justice in turnover intentions, job satisfaction, and organizational citizenship behavior in hospitality industry. International journal of hospitality management, 29(1), pp.33-41.

28. O'Neill, J. W. and Davis, K., 2011. Work stress and well-being in the hotel industry. International journal of hospitality management, 30(2), pp.385-390.

29. Pavlović, M. i Marković, D., 2014. Teorijski pristup zadovoljstvu poslom i motivaciji zaposlenih. Vojno delo, 66(1), str. 289-302.

30. Perić, G., Gasic, M., Stojiljkovic, M. and Nešić, I., 2018. The impact of employee satisfaction on the tourist satisfaction with the services of spa tourism. Economics of Agriculture, 65(2), pp.617-632. 
31. Perić G., Gašić, M., Ivanović, V. i Stojiljković, M., 2015. Zadovoljstvo zaposlenih u banjskim turističkim destinacijama Srbije. Bizinfo (Blace), 6(2), str.1-15.

32. Perić, G., Mihajlov, S., Gasic, M. and Stojiljkovic, M., 2015. Research of employee satisfaction in tourism center Vrnjačka Spa. Management and Education, 11(2), pp.26-34.

33. Perić, G., 2014. Nagrađivanje u funkciji povećanja zadovoljstva i motivacije zaposlenih u banjskim turističkim centrima. Specijalistički akademski rad. Beograd: Fakultet organizacionih nauka Univerziteta u Beogradu.

34. Rast, S. and Tourani, A., 2012. Evaluation of employees' job satisfaction and role of gender difference: An empirical study at airline industry in Iran. International Journal of Business and Social Science, 3(7), pp.91-100.

35. Robbins, S. and Judge, T., 2010. Organizacijsko ponašanje. Zagreb: Mate Zagreb.

36. Sageer, A., Rafat, S. and Agarwal, P., 2012. Identification of variables affecting employee satisfaction and their impact on the organization. IOSR Journal of business and management, 5(1), pp.3239.

37. Statt, D., 2004. The Routledge Dictionary of Business Management, Third edition. Detroit: Routledge Publishing.

38. Sousa-Poza, A. and Sousa-Poza, A. A., 2003. Gender differences in job satisfaction in Great Britain, 1991-2000: permanent or transitory?. Applied Economics Letters, 10(11), pp.691-694.

39. Singh, J. K. and Jain, M., 2013. A Study of employee's job satisfaction and its impact on their performance. Journal of Indian research, 1(4), pp.105-111.

40. Tuna, M., Ghazzawi, I., Yesiltas, M., Tuna, A. A. and Arslan, S., 2016. The effects of the perceived external prestige of the organization on employee deviant workplace behavior: The mediating role of job satisfaction. International Journal of Contemporary Hospitality Management, 28(2), pp.366-396.

41. Tepeci, M. and Bartlett, A. B., 2002. The hospitality industry culture profile: a measure of individual values, organizational culture, and person-organization fit as predictors of job satisfaction and behavioral intentions. International Journal of Hospitality Management, 21(2), pp.151-170.

42. Tian, X. and Pu, Y., 2008. An artificial neural network approach to hotel employee satisfaction: The case of China. Social Behavior and Personality: an international journal, 36(4), pp.467-482.

43. Urošević, S. and Milijić, N., 2012. Influence of demographic factors on employee satisfaction and motivation. Organizacija, 45(4), pp.174182. 
EMPLOYEE SATISFACTION IN HOTEL INDUSTRY: THE CASE OF HOTEL RADAN IN PROLOM BANJA

44. Verhofstadt, E., De Witte, H. and Omey, E., 2007. Higher educated workers: better jobs but less satisfied?. International Journal of Manpower, 28(2), pp.135-151.

45. Yee, R. W., Yeung, A. C. and Cheng, T. E., 2008. The impact of employee satisfaction on quality and profitability in high-contact service industries. Journal of operations management, 26(5), pp.651668

46. Zhen, L. and Jie, Y., 2009, December. A study on job satisfaction of hotel employees. In Information Management, Innovation Management and Industrial Engineering, 2009 International Conference on (Vol. 4, pp. 204-209). IEEE.

Received: 13 November, 2019

Accepted: 16 December, 2019

Rad je primljen: 13.11.2019.

Prihvaćen za objavljivanje: 16.12.2019. 
